Available online at GSC Online Press Directory

GSC Biological and Pharmaceutical Sciences

e-ISSN: 2581-3250, CODEN (USA): GBPSC2

Journal homepage: https://www.gsconlinepress.com/journals/gscbps

(RESEARCH ARTICLE)

\title{
Efficacy of Sida cordifolia Linn. decoction as vehicle of drug (anupanam) in the management of joint disorders
}

\author{
Pholtan Rajeev S. R. * \\ Department of Siddha Toxicology, The Tamil Nadu Dr. M. G. R. Medical University, Chennai, Tamil Nadu, India.
}

Publication history: Received on 25 July 2020; revised on 05 August 2020; accepted on 04 September 2020

Article DOI: https://doi.org/10.30574/gscbps.2020.12.3.0240

\begin{abstract}
In $21^{\text {st }}$ century, whole world is returning back to ancient life style. As a huge medical system, herbal drugs are very effective for many diseases. However, Arthritis also controls by herbal drugs even though not efficiency reducing the symptoms of joint pain. This is the identified problem. Therefore, this research tries to correct that problem by treating vehicle (anupanam) with herbal medicine formula. In commonly patients are suffering from joint pain caused by Arthritis. This research was finding-out the efficacy of Sittamatti (Bala- Sida cordifolia Linn) decoction as an anupanam (Vehicle of drug). Control clinical study measured to assess the effect of the treatment by significant relief of symptoms of Arthritis within three months. This research is clinical control study and qualitative analysis research. Selection of samples (60 samples) and same time preparation of our new research drug is initial works. There after data collections and observation of the progress of the effect of the research drug. Finally, analyzed by the tables, charts and statistical way. According to tables, charts results; every table explained various angle of collection of the data and observations with sum of numbers and percentage level. Male samples are $60 \%$, and Females are $40 \%$ in total sample population in research. $73.3 \%$ - High Marked improvement, $26.6 \%$ - Moderate improvement is this research result of whole results. Therefore, anupanam with medicine (Group-I) is best than medicine without anupanam (Group-II). Vatha Gajendra Singhe Rasa with Sida decoction, Mudakku Chooranam with Sida decoction treatment are better clinically efficacy than Vatha Gajendra Singhe Rasa without Sida decoction, Mudakku Chooranam without Sida decoction treatment.In statistical result says, compare with sample group-I \& sample group-II was 0.0001 ( $p$ value $<0.05$ ) within three month of treatment. Finally, we concluded effectiveness of our vehicle with medicine most effective than medicine control Group -II for symptoms of joint disorder significantly. In Arthritis symptoms, Joint Pain, tenderness, limitation of movements and swelling was highly notified changes as reducing within three months all symptoms.
\end{abstract}

Keywords: Sida cordifolia Linn; Decoction; Anupanam (Vehicle of drug); Joint Pain; Ayurvedic medicines.

\section{Introduction}

Symptoms of Joint disorders are compared with symptoms of keel vaatham in siddha system of medicine. Keel vaatham is mentioned under vaatha noi by all Siddhars. It can define as a disease of joint with symptoms of joint pain, joint swelling, limitation and painful movements, restricted joint movement. Osteoarthritis is the most articular disorder begins asymptomatically in the second and third decade and is extremely common by age 60 years. Almost all persons by age 40 years have some pathologic change in weight bearing joint particularly in knee joint. $40 \%$ females and $60 \%$ males have symptomatic Osteoarthritis. No treatment is available which can prevent the disease process. In medical science, mainly analgesics, anti-inflammatory drugs or finally surgery are the options for the treatment of Osteoarthritis. Considering all these factors, the present study was taken up with the objective to evaluate the efficacy of herbal medicine with vehicle (Anupanam) to keel vaatham (osteoarthritis). Anupanam is the main roll in administration of drug

\footnotetext{
${ }^{*}$ Corresponding author: Pholtan Rajeev S. R.

Department of Siddha Toxicology, The Tamil Nadu Dr. M. G. R. Medical University, Chennai, Tamil Nadu, India.
} 
in Siddha system and Ayurvedic system of medicine. One medicine cures many diseases by changing of Annupanam is special characteristic of poly herbal medicine. Combination of Vatha Gajendra Singhe Rasa and Mudakku Chooranam medicines are normally reduce symptoms of Arthritis but this research enhances the most effective than other drugs for arthritis are medicine with anupanam. Selected commonly used anti-arthritis treatment plan and that involve to research for identify better treatment with anupanam.

Sida cordifolia (Bala, Country Mallow, Heart-Leaf Sida or Flannel Weed) is a perennial subshrub of the mallow family Malvaceae native to India \& Sri Lanka. It has naturalized throughout the world, and is considered an invasive weed in Africa, Australia, the southern United States, Hawaiian Islands, New Guinea, and French Polynesia. The specific name, cordifolia, refers to the heart-shaped leaf. [6] Common Name: Indian Ephedra, Mallow plant, Janglimedhi, Bala, Vatya, Bariyar, Kharethi, Tamil: Sitamati / Chittamati, Sanskrit: Bala, Sinhala: Babila (Sulu boo Babila), English: Yellow sticky Mallon. Part Used: Roots and leaves, whole plant. [6] Sida Cordifolia, an erect, minutely hairy and branched under shrub with a firm woody stem and intricate branches, contains $0.8 \%$ to $1.2 \%$ of the alkaloid ephedrine. It has been used by Ayurveda as a rejuvenating herb and an aphrodisiac. [6]

\subsection{Organoleptic Characters}

Taste (suwai) - Astringent, Veerya (thanmai) - Cooling (Seetha), Viphaka (pirivu) - Sweet [3] Properties: Sida cordifolia has ephedrine and pseudo-ephedrine along with other compounds as active ingredients that stimulate the cardiovascular system and CNS. It is considered to have diaphoretic, diuretic, central nervous system stimulating and antiasthmatic properties. The stem of Sida cordifolia contains a number of active compounds, including small amounts of an essential oil, 1-2\% alkaloids composed mainly of ephedrine and pseudoephedrine, with ephedrine ranging from 30$90 \%$, depending on the source. It is a rejuvenating herb, an aphrodisiac herb which helps in curing those diseases that occur due to inflammation of the nerves. [6] Actions: Emollient, Astringent, Stomachic, Diuretic [6]

\subsection{Medicinal use}

S. cordifolia is used in Ayurvedic medicine, known as "malva branca", is a plant used in the folk medicine for the treatment of inflammation of the oral mucosa, blenorrhea, asthmatic bronchitis and nasal congestion, stomatits, of asthma and nasal congestion and in many parts of Africa for various ailments, particularly for respiratory problems. It has been investigated as an anti-inflammatory, for treating cancer, and for encouraging liver re-growth. Due to its ephedrine content, it possesses psychostimulant properties, affecting the central nervous system and also the heart. [6] Sida Cordifolia has been used in India for over 2,000 years now to treat a variety of health disorders like bronchial asthma, cold \& flu, chills, lack of perspiration, headache, nasal congestion, aching joints and bones, cough \& wheezing, and edema. One of its uses is in weight loss too as the ephedrine alkaloids control metabolism in human body. It is one of the best medicines for Rheumatism, cardiac tonic. It is beneficial in nervous and urinary diseases, bleeding piles, hematuria, gonorrhea, cystitis, leucorrhea, chronic dysentery, nervous disorders, insanity, asthma and disorders of blood and liver. Fresh decoction mixed with ginger is used for intermittent fever with cold shivering fits. The root is pounded and applied for elephantiasis to reduce pain. The root is processed with milk and used internally and externally for hemiplegia, stiff neck, facial paralysis, diseases of the nervous system, and diseases of nose, ear, mouth and head. Its herbal extract or tea is used for obesity and obesity related disorders, especially in western countries. It is used for all kinds of detoxification and rejuvenation therapies like in medicated enema where its root extract is used for all kinds of nervous disorders like paralysis, arthritis etc. In one of the rejuvenation therapies named "Navara Kizhi", medicated Navara (rice) with milk and Sida cordifolia is applied all over the body or to a particular body part. In condition of sexual weakness, the milk extract of Sida cordifolia root is recommended as an effective remedy for sperm mobility and low sperm count disorders. [6]

\subsection{Prepared Siddha Medicines}

Sittamati Kudineer, Bala vilva sundi Kudineer, Lipakathy Himbatu Kudineer, Thasamoola Kudineer, Seeraka Leheyam Karisalai Leheyam Thalankai Ennai, Arukam vaer Thailam, Araku Sandanaty Thailam, Sittamati ennai, Meha Sanjeevi Kuzhmbu, Sittamati Madaku Thailam [1], [2].

\subsection{Perpared Ayurveda Medicines}

Bala Arista, Dashamoolarista, Dashamooladi Quatha, Dantheemoola Bala Shuntyadi Quatha, Aravindasawa, Punarnavadyarista [1], [2].

In this research selected 60 research samples. In 30 samples for only common treatment (control group) and other 30 samples involved with research anupanam with common treatment. This is conducted in District Ayurvedic Hospital, Mulliyawalai, Sri Lanka. Permission and Ethical Clearance are given by the Provincial Commissioner of Indigenous 
medicine, Northern Province, Sri Lanka. Samples were follow-up with their measurements in once in two weeks altogether 03 months duration data collected and studied by scientific research methodology. In this research is help to prove scientifically that indigenous medical systems' theory as co-drug or anupanam for effective treatment and management of diseases. Objectives were; To relief the Symptoms of Arthritis through Herbal Medicine. To identify effectiveness of anupanam. To evaluate efficacy of combination of drug and anupanam for joint disorders.

\section{Material and methods}

Type of Research: Control -Clinical Study

Research area: District Ayurvedic Hospital (DAH), Mullaitivu, Sri Lanka

Research Samples: 60 patients

Identification of Arthritis patients according to clinically diagnosis.

Parameters Measured

The parameters measured were both objective and subjective.

Subjective parameters included pain, tenderness, swelling, and crepitation

\subsection{Inclusive criteria}

Patients were eligible if they were 21-75 years of age, had according to the known joint disorder patients by past diagnostic medical report, were treated with diet, oral anti-arthritic agents, and had evidence of symptomatic symmetrical or Asymmetrical Arthritis.

\subsection{Exclusive criteria}

Were the following: Presence of foot ulcers, peripheral vascular disease (non-palpable foot pulses, intermittent claudication), myopathy, causes of Arthritis by significant neurological diseases, participation in a study of any investigational drug for Arthritis within the 3 months before the study, use of oral or external anti-arthritic agents within 1 month before the study, severe concomitant diseases, and pregnancy, lactation, or childbearing age without birth control devices. Recently fractured part pain involvement. any other NCDs or systemic diseases.

- $\quad$ Literature review

- 2.1) Identify and authenticate the drug materials including in the selected formula.

- Identify the treatment in Siddha Pharmacopoeia

- Making for sample and check the quality for phyto-chemicals \& standardization

- Clinical test for the drug from 60 patients in OPD (Out Patient Department) and data collecting from a suitable Proforma

- Institutional Ethical Committee approval got from Provincial Department of Indigenous Medicine, Northern Province, Jaffna (No: NP/IEC/MUL/2013/001-C)

- Assessment Criteria

\section{Final Assessment Criteria}

- $\quad$ High Marked. (not cured)

- Marked improvement.

- Moderate improvement.

- Mild improvement.

- Very mild.

- Not improvement.

- Aggressive. 


\subsection{Analysis of the data and making the thesis}

Qualitative Scoring analysis:

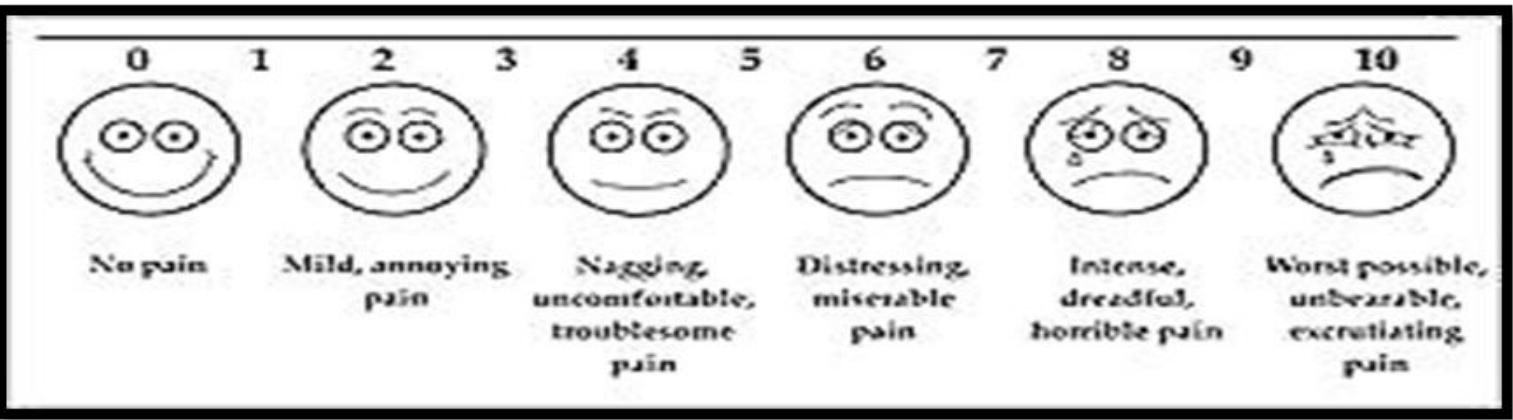

\begin{tabular}{|c|c|c|c|c|c|c|c|c|c|c|}
\hline \multicolumn{11}{|c|}{ Seore: } \\
\hline 0 & 1 & 2 & 3 & 4 & 5 & 6 & 7 & 8 & 9 & 10 \\
\hline \multicolumn{11}{|c|}{ initial } \\
\hline \multicolumn{3}{|c|}{ Very Mild } & & \multicolumn{2}{|c|}{ Mild } & \multicolumn{2}{|c|}{ Moderate } & & \multicolumn{2}{|c|}{ Severe } \\
\hline \multicolumn{11}{|c|}{ final } \\
\hline \multicolumn{3}{|c|}{ High Marked } & & \multicolumn{2}{|c|}{ Moderate } & \multicolumn{2}{|c|}{ Mild } & & \multicolumn{2}{|c|}{ Very Mild } \\
\hline
\end{tabular}

\subsection{Drug preparation}

Prepared Research drug - vehicle of drug (anupanam) with medicine and control drug as without anupanam which as change compares.

\subsubsection{Research drug}

\subsubsection{Anupanam (vehicle) Ingredients}

Sittamatti Sida cordifolia Linn.Whole plant

(Decoction pack is in annexure)

\subsubsection{Method of preparation}

Normal Decoction preparation. Add 08 cups of water then heat and reduction for 01 cup for 01 day.

Research drug: Medicine + Anupanam (Anupanam: Sittamatti decoction)

Sida cordifolia confirmed (Through Herbariums) by Dr. (Mrs). V. Sathiyaseelan, Senior Lecturer, Sectional Head, Materia medica, Unit of Siddha Medicine, University of Jaffna. And Dr. (Mrs). Sudeepa Sugathasa, Scientist (Pharmacognosy), InCharge, Botany Section, Bandaranake Memorial Ayurvedic Research Institute (BMARI), Nawinna.

Control drug: Medicine only

\subsection{Clinical study}

Clinical trial for research drug and Compare drugs to 60 patients in OPD (Out Patient Department) and data collecting from a suitable Proforma. 


\subsubsection{Grouping the Samples}

In this research, total sample divided into two (02) groups but all are same symptomatically Arthritis condition. Those two groups are given below,

- Group I: Arthritis patients with medicine + Sittamatti decoction treatment (30 patients).

- Group II: Arthritis patients with medicine without anupanam treatment without any decoction or liquid formulas (30 patients).

Treatment is as follows

\section{Group: I (Research drug)}

\begin{tabular}{|l|l|l|l|}
\hline Medicine & Dosage & Period of intake & Vehicle (Anupana) \\
\hline Vathagajendra singhe rasa [4] & 02 pills & Twice a day & Sittamatti decoction \\
\hline Mudakku Chooranam [1] & $01 \mathrm{~g}$ & Thrice a day & Sittamatti decoction \\
\hline
\end{tabular}

\section{Group: II (Control drug)}

\begin{tabular}{|l|l|l|l|}
\hline Medicine & Dosage & Period of intake & Vehicle (Anupana) \\
\hline Vathagajendra singhe rasa & 02 pills & Twice a day & - \\
\hline Mudakku Chooranam & $01 \mathrm{~g}$ & Thrice a day & - \\
\hline
\end{tabular}

\subsubsection{Vatha Gajendra Singhe Rasa [4]}

It is commonly used as anti-arthritis treatment in Sri Lanka. It is Ayurvedic Medicine.

\subsubsection{Mudakku Chooranam [1]}

It is commonly used as anti-arthritis treatment in Northern part of Sri Lanka. It is Siddha Medicine.

Combination of Vatha Gajendra Singhe Rasa and Mudakku Chooranam medicines are normally reduce symptoms of arthritis but this research enhance the most effective than other drugs for arthritis is medicine with anupanam.

\subsubsection{Ethical Clearance}

Ethical clearance got from Provincial Commissioner of Indigenous Medicine, Northern Province, Sri Lanka. (No: NP/IEC/MUL/2013/001-C)

\subsubsection{Clinical Trial}

Clinical consultation and follow-up the patients in District Ayurvedic Hospital (DAH), Mullaitivu, Sri Lanka.

\subsection{Data Collection}

Selected samples with modified Proforma.

Symptoms measured as qualitative measures with grading score.

\subsection{Statistical Analysis}

Statistical analysis with Minitab software. 


\section{Results and discussion}
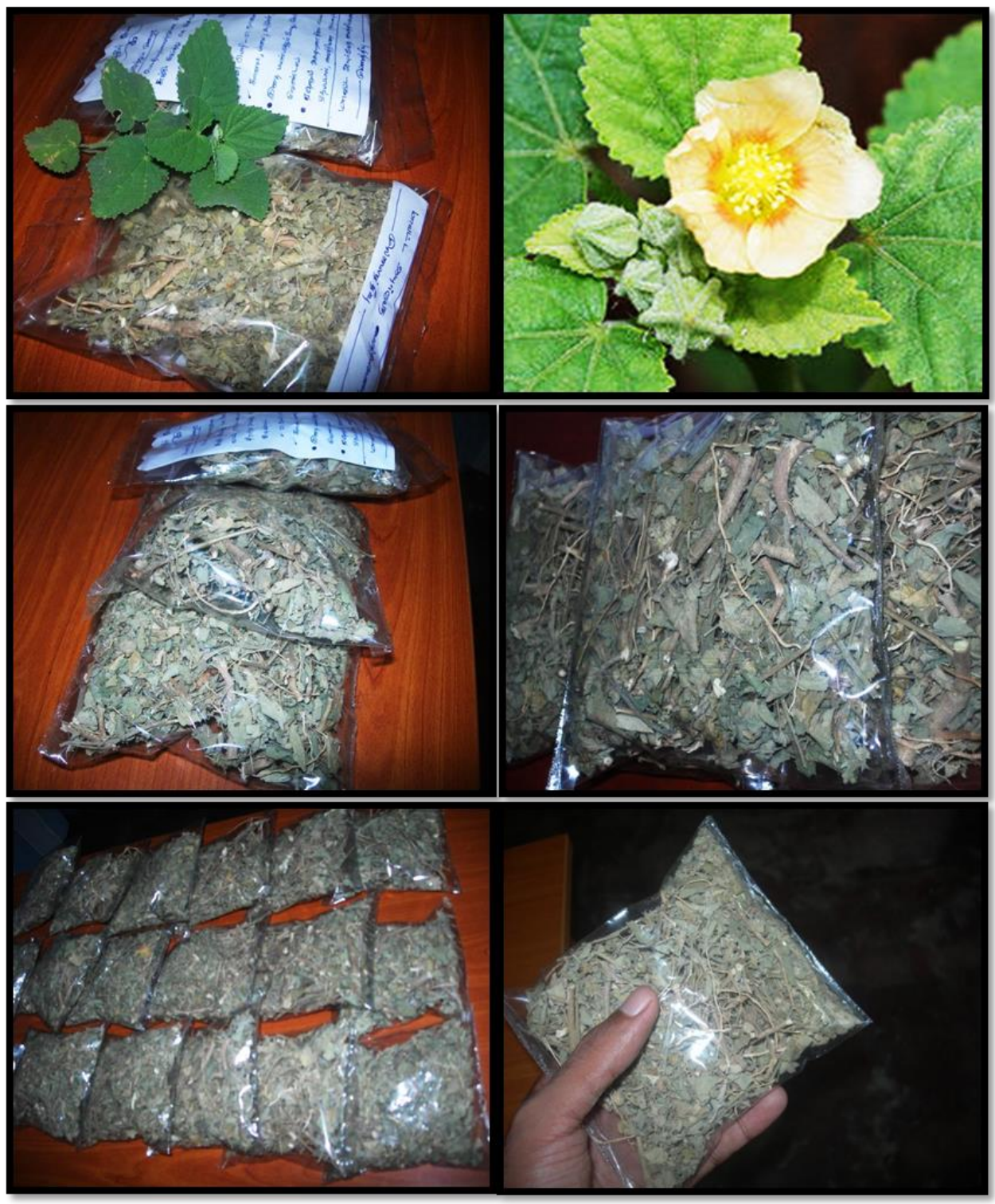

Figure 2 Anupanam as; Decoction pack of Sida cordifolia Linn.

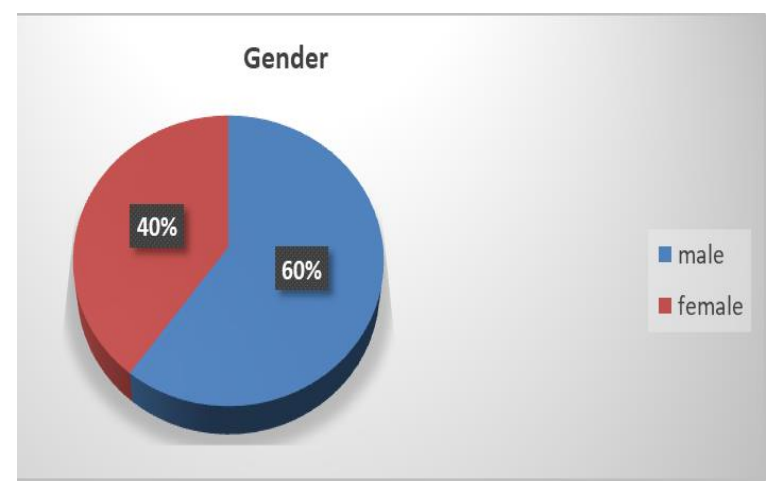

Chart 112 samples are female of 30 total samples in research. This is $40 \%$ in total sample. 18 samples are male of 30 total samples in research. Male samples are $60 \%$ in total sample. 
Table 3 Samples and Main Complaint

\begin{tabular}{|c|c|c|c|c|}
\hline No. & Sample No. & Sex & Age & Symptom \\
\hline 1 & 1 & $\mathrm{~F}$ & 35 & pain in both knee joint \\
\hline 2 & 2 & M & 38 & pain and swelling in knee joint \\
\hline 3 & 3 & M & 29 & tenderness in shoulder \\
\hline 4 & 4 & M & 45 & pain in right knee joint \\
\hline 5 & 5 & $\mathrm{~F}$ & 67 & pain in left knee joint \\
\hline 6 & 6 & $\mathrm{~F}$ & 70 & pain in left knee joint \\
\hline 7 & 7 & M & 69 & pain and swelling in knee joint \\
\hline 8 & 8 & M & 43 & pain and swelling in knee joint \\
\hline 9 & 9 & $\mathrm{~F}$ & 54 & pain and swelling in knee joint \\
\hline 10 & 10 & $\mathrm{~F}$ & 58 & pain in both knee joint \\
\hline 11 & 11 & $\mathrm{~F}$ & 39 & pain in both knee joint \\
\hline 12 & 12 & M & 60 & pain in both knee joint \\
\hline 13 & 13 & M & 55 & pain in both knee joint \\
\hline 14 & 14 & M & 45 & pain and swelling in knee joint \\
\hline 15 & 15 & $\mathrm{~F}$ & 62 & tenderness in shoulder \\
\hline 16 & 16 & M & 64 & pain in right knee joint \\
\hline 17 & 17 & $\mathrm{~F}$ & 58 & pain in right knee joint \\
\hline 18 & 18 & M & 37 & pain and swelling in knee joint \\
\hline 19 & 19 & M & 42 & pain in both knee joint \\
\hline 20 & 20 & M & 40 & pain in both knee joint \\
\hline 21 & 21 & M & 52 & pain in both knee joint \\
\hline 22 & 22 & $\mathrm{~F}$ & 46 & tenderness in shoulder \\
\hline 23 & 23 & M & 49 & pain in left knee joint \\
\hline 24 & 24 & M & 38 & pain in right knee joint \\
\hline 25 & 25 & M & 45 & pain in left knee joint \\
\hline 26 & 26 & $\mathrm{~F}$ & 56 & pain in right knee joint \\
\hline 27 & 27 & $\mathrm{~F}$ & 52 & pain and swelling in knee joint \\
\hline 28 & 28 & M & 59 & pain and swelling in knee joint \\
\hline 29 & 29 & $\mathrm{~F}$ & 60 & pain in both knee joint \\
\hline 30 & 30 & M & 70 & pain in both knee joint \\
\hline
\end{tabular}




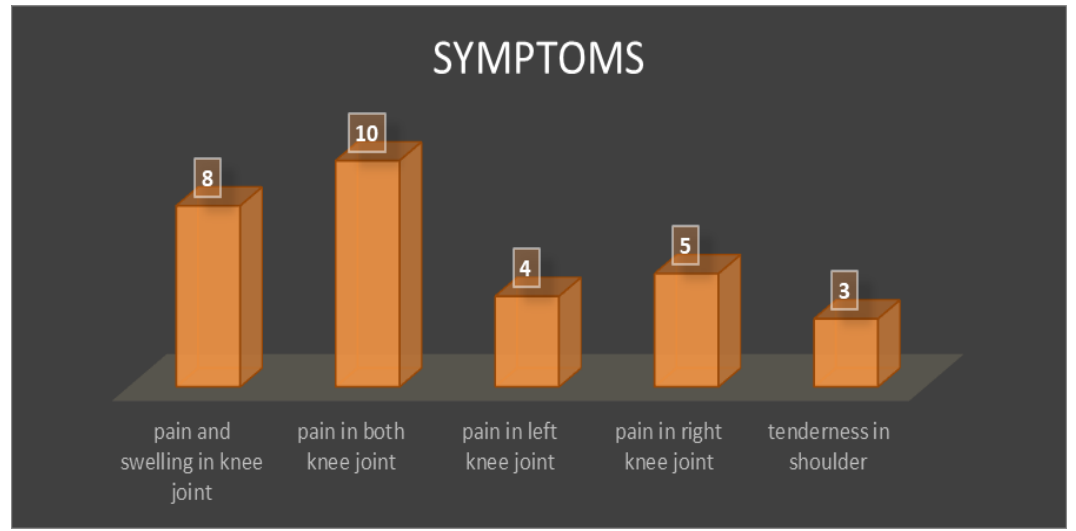

Chart 2 Symptoms of samples

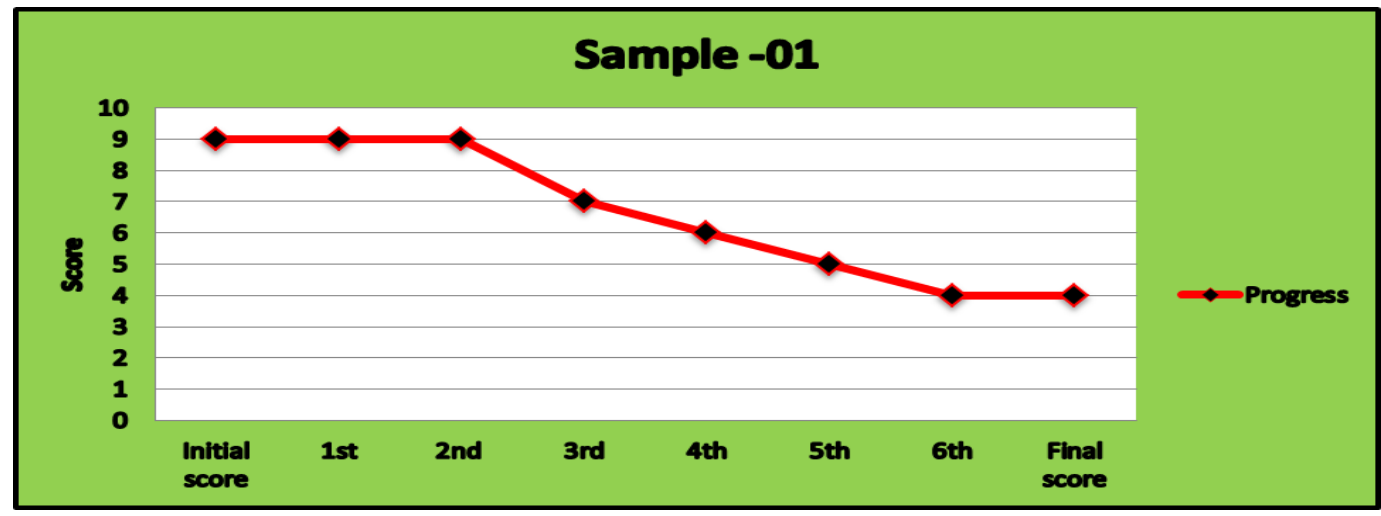

Chart 03 Once in two weeks follow-up the patients and their progress in each samples for research with grading

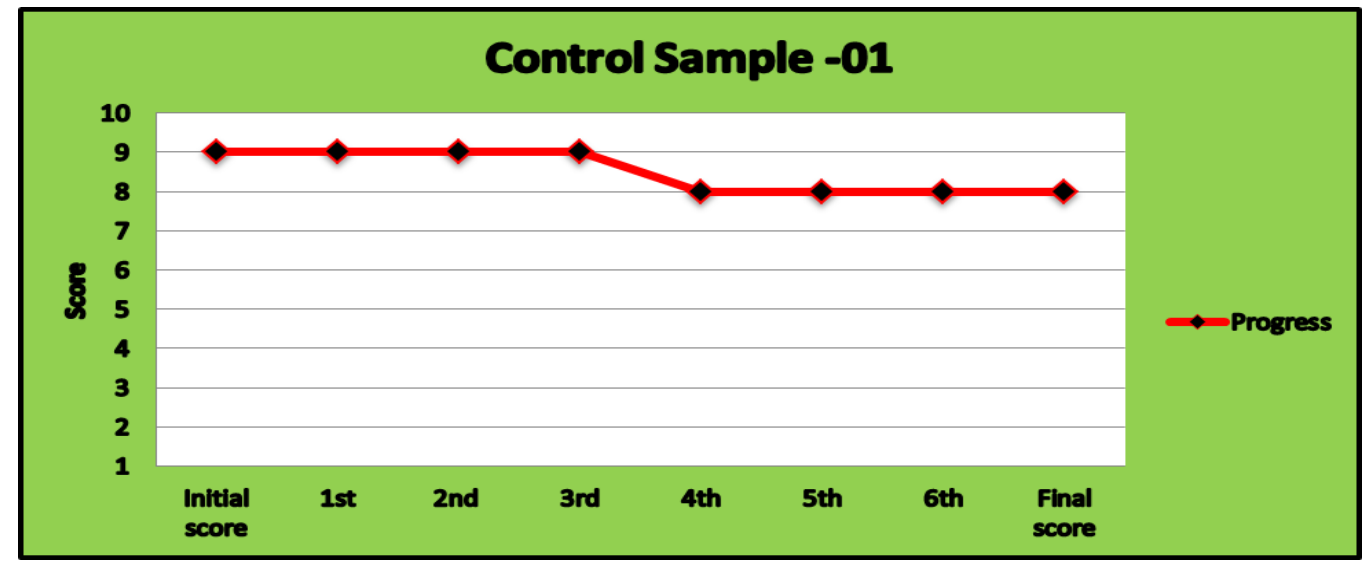

Chart 04 Once in two weeks follow-up the patients and their progress in each control samples for research with grading score. 
Table 4 Initial and final score of joint pain

\begin{tabular}{|c|c|c|c|c|c|}
\hline Sample No. & Sex & Age & Symptom & Initial score & Final score \\
\hline 1 & $\mathrm{~F}$ & 35 & pain in both knee joint & 9 & 4 \\
\hline 2 & $\mathrm{M}$ & 38 & pain and swelling in knee joint & 8 & 4 \\
\hline 3 & M & 29 & tenderness in shoulder & 5 & 1 \\
\hline 4 & M & 45 & pain in right knee joint & 10 & 3 \\
\hline 5 & $\mathrm{~F}$ & 67 & pain in left knee joint & 7 & 2 \\
\hline 6 & $\mathrm{~F}$ & 70 & pain in left knee joint & 8 & 3 \\
\hline 7 & $\mathrm{M}$ & 69 & pain and swelling in knee joint & 9 & 5 \\
\hline 8 & M & 43 & pain and swelling in knee joint & 9 & 4 \\
\hline 9 & $\mathrm{~F}$ & 54 & pain and swelling in knee joint & 9 & 4 \\
\hline 10 & $\mathrm{~F}$ & 58 & pain in both knee joint & 7 & 2 \\
\hline 11 & $\mathrm{~F}$ & 39 & pain in both knee joint & 5 & 1 \\
\hline 12 & M & 60 & pain in both knee joint & 8 & 2 \\
\hline 13 & $\mathrm{M}$ & 55 & pain in both knee joint & 10 & 2 \\
\hline 14 & M & 45 & pain and swelling in knee joint & 9 & 2 \\
\hline 15 & $\mathrm{~F}$ & 62 & tenderness in shoulder & 9 & 3 \\
\hline 16 & $\mathrm{M}$ & 64 & pain in right knee joint & 7 & 1 \\
\hline 17 & $\mathrm{~F}$ & 58 & pain in right knee joint & 5 & 1 \\
\hline 18 & $\mathrm{M}$ & 37 & pain and swelling in knee joint & 9 & 1 \\
\hline 19 & $\mathrm{M}$ & 42 & pain in both knee joint & 8 & 2 \\
\hline 20 & M & 40 & pain in both knee joint & 5 & 1 \\
\hline 21 & $\mathrm{M}$ & 52 & pain in both knee joint & 10 & 1 \\
\hline 22 & $\mathrm{~F}$ & 46 & tenderness in shoulder & 7 & 1 \\
\hline 23 & $\mathrm{M}$ & 49 & pain in left knee joint & 8 & 2 \\
\hline 24 & $\mathrm{M}$ & 38 & pain in right knee joint & 9 & 2 \\
\hline 25 & $\mathrm{M}$ & 45 & pain in left knee joint & 9 & 1 \\
\hline 26 & $\mathrm{~F}$ & 56 & pain in right knee joint & 9 & 1 \\
\hline 27 & $\mathrm{~F}$ & 52 & pain and swelling in knee joint & 8 & 1 \\
\hline 28 & $\mathrm{M}$ & 59 & pain and swelling in knee joint & 10 & 1 \\
\hline 29 & $\mathrm{~F}$ & 60 & pain in both knee joint & 9 & 2 \\
\hline 30 & $\mathrm{M}$ & 70 & pain in both knee joint & 7 & 1 \\
\hline
\end{tabular}

End of the research finding is above table. Initial score of the samples and final score of samples are listed above. (n=30) 


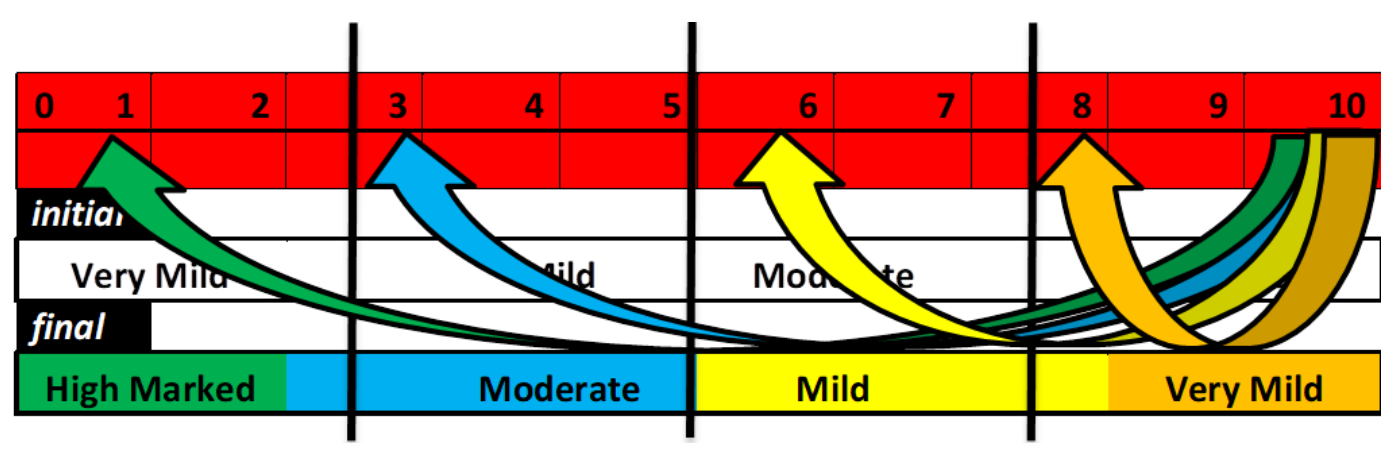

Figure 3 Obtained result through the pain score

\section{Discussion}

Symptoms of joint disorders; Symptoms of Joint disorders are compared with symptoms of keel vaatham in siddha system of medicine. Keel vaatham is mentioned under vaatha noi by all Siddhars. It can define as a disease of joint with symptoms of joint pain, joint swelling, limitation and painful movements, restricted joint movement. Results are;

- 12 samples are female of 30 total samples in research. Females are $40 \%$ in total sample.

- 18 samples are female of 30 total samples in research. Male samples are $60 \%$ in sample

- 08 samples complaint pain and swelling in knee joint. This is $26.6 \%$ of research samples.

- 10 samples are complaint pain in both knee joints. This is $70 \%$ of total samples.

- Only 04 samples are complaint pain in left knee joint. This is $13.3 \%$ of total sample.

- Only 05 samples are complaint pain in right knee joint. This is $16.6 \%$ of sample.

- Only 03 samples are complaint tenderness in shoulder. This is $10 \%$ of samples research.

- End of the research finding is above table. Initial score of the samples and final score of samples are listed above. $(\mathrm{n}=30)$ Assessment of scoring;

- Initial score is $05-13.3 \%$, Initial score is $07-16.6 \%$, Initial score is $08-20 \%$, Initial score is $09-36.7 \%$, Initial score is $10-13.3 \%$ and Final score is $01-43.3 \%$, Final score is $02-30 \%$, Final score is $03-10 \%$, Final score is $04-13.3 \%$, Final score is $05-03.3 \%$

Grading Score

Final Score is $(01,02)-43.3 \%+30.0 \%=73.3 \%-$ High Marked improvement

Final Score is $(03,04,05) 10 \%+13.3 \%+03.3 \%=26.6 \%$ - Moderate improvement

73.3\% - High Marked improvement, 26.6\% - Moderate improvement is this research result of whole result. Therefore anupanam with medicine (Group-I) is best than medicine without anupanam (Group-II). Vatha Gajendra Singhe Rasa with Sida decoction, Mudakku Chooranam with Sida decoction treatment are better clinically efficacy than Vatha Gajendra Singhe Rasa without Sida decoction, Mudakku Chooranam without Sida decoction treatment.

\section{Conclusion}

In statistical result says, compare with sample group-I \& sample group-II was 0.0001 (p value $<0.05$ ) within three month of treatment. Finally, we concluded effectiveness of our vehicle with medicine most effective than medicine control Group -II for symptoms of joint disorder significantly.

\section{Compliance with ethical standards}

\section{Acknowledgments}

I sincerely thank to Dr. (Mrs). S. Thurairatnam, Provincial Commissioner of Indigenous Medicine, Northern Province for grant permission to do research and clearances of ethics of clinical trial research. I thank to authentication of raw material (Sida cordifolia) by Dr. (Mrs). Vivian Sathiyaseelan, Senior Lecturer, In-Charge of Materia Medica, Unit of Siddha medicine, University of Jaffna. And Scientist (Pharmacognosy) Mrs. Sudeepa Sugathadasa In-Charge Botany section, 
BMARI, Nawinna, Sri Lanka. Finally thank to labourers of District Ayurvedic Hospital (DAH), Mullaitivu for collecting, preparation and packing of research decoction packs of research drug.

\section{Disclosure of conflict of interest}

The author declared that no conflict of interest.

\section{Statement of ethical approval}

This research study's Clinical trial and follow-up the patients in District Ayurvedic Hospital (DAH), Mullaitivu, Sri Lanka with the approval of Ethical committee clearance got from Provincial Commissioner of Indigenous Medicine, Northern Province, Sri Lanka. (No: NP/IEC/MUL/2013/001-C)

\section{Statement of informed consent}

Informed consent was obtained from all individual participants included in the study.

\section{References}

[1] Anonymous, Ayurveda Pharmacopoeia of Sri Lanka, Department of Ayurveda. 1976; 35- 40.

[2] Krithigar and Basu, Indian Medicinal Plants, vol-III, third edition, 1997.

[3] Kumar RS, Mishra SH. Anti-inflammatory and hepatoprotective activities of Sida cordifolia Linn. Ind J Pharmacol . 1997; 110-16.

[4] Mediros IA, Santos MRV, Nascimento NMS, Duarte JC. Cardiovascular effects of Sida cordifolia leave extract in rats. Fitoterapia. 2005.

[5] Murugesa muthaliyar. KS. Gunapadam- Mooligai thokuppu (1st Part), University of Indian Medicine, Madras600 106, 3nd Edition- 1936.

[6] Narayanaswami.V, HPIM, 'Pharmacopoeia of Hospital of Indian Medicine - SIDDHA', Tamil Nadu Siddha Medical Board, Madras-600 106, 2nd Edition-1995; 29.

[7] Narkarni K. Indian Materia Medica, vol-1, second edition. 1993.

[8] Nayar, Chopra. Glossary Indian med: plants, PID. New Delhi. 1956; 227.

[9] Pole, Sebastian. Ayurvedic medicine. Elsevier Health Sciences. 2006; 137.

[10] Ponnaiyah. I, Sekarasa sekara vaiththiyam Provincial Department of Indigenous Medicine, North-East Province, Sri Lanka. 2000; 115.

[11] Ramanathan. P, MD(s), 'Siddha Pharmacopoeia', All Sri Lankan Siddha Ayurveda Medical Officers' Union, Sri Lanka, 1st Edition-2000; 102.

[12] Rangari VD.Pharmacognosy and Phytochemistry. Part II; first edition. 2000; 274-275.

[13] Silva RL, Melo GB, Melo VA, Antoniolli AR, Michellone PR, Zucoloto S, Picinato MA, Franco CF et al. Effect of the aqueous extract of Sida cordifolia on liver regeneration after partial hepatectomy. Acta cirurgica brasileira / Sociedade Brasileira para Desenvolvimento Pesquisa em Cirurgia 21 Suppl 1 2006; 37-9.

[14] Silva RS et al. Effect of the aqueous extract of Sida cordifolia on liver regeneration after partial hepatectomy. Acta Cir. 2006; 21(1) : 77-79.

[15] Sumanth Meera and Mustafa S. S., Antistress and Adoptogenic Activity of Sida cordifolia Roots in Mice, Ind J Pharm Sci. 2009 May-Jun; 71(3): 323-324.

[16] WHO. monograph on selected medicinal plants. Vol. I and II. 1996; 97. 


\section{Author's short biography}

Dr. S. R. Pholtan Rajeev
Dr. S. R. Pholtan Rajeev, finished BSMS in Jaffna University, Sri Lanka and worked as Medical Officer at
District Ayurvedic Hospital, Mullaitivu, Sri Lanka and Central Ayurvedic Dispensary in Vaharai,
Batticaloa, Sri Lanka as contract basis. Finally, working as Medical Officer in Provincial Department of
Indigenous Medicine, Eastern Province, Trincomalee, Sri Lanka since 2014 permanently. Now doing
Post Graduate - MD(S) in The Tamil Nadu Dr. M. G. R. Medical University, Chennai, Tamil Nadu from
2018.

